\title{
Improved Performance of a Microbial Fuel Cell with Polypyrrole/Carbon Black Composite Coated Carbon Paper Anodes
}

\author{
Yong Yuan and Sunghyun Kim* \\ Department of Bioscience and Biotechnology: Konktik Lntersity, Seoul 143-701, Korea. "E-mail: skimlooakonkukackr \\ Received Februarv 27, 2008
}

\begin{abstract}
A microbial fuel cell (MFC) has been regarded as noble clean energy technology that can directly convert biomass to electricity. However its low power density is a main limitation to be used as a new energy source. To overcome this limitation. we focused on the anode improvement in a mediator-type MFC using $P$. vulgaris as a biocatalyst. Fuel cell performance increased when the anode was coated with carbon black or polypyrrole. The best performance was observed when polypy rrole/carbon black (Ppy/CB) composite material was coated on a carbon paper electrode. Our obtained value of $452 \mathrm{~mW} \mathrm{~m}^{-2}$ is the highest value among the reported ones for the similar sỵstem. The effects of amount of Ppy/CB, mediator concentration, and amount of $P$. vu/garis have also been examined.
\end{abstract}

Key Words : Microbial fuel cell. Polypyrrole/carbon black. Electrode modification. Impedance spectroscopy

\section{Introduction}

In recent years the interest in renewable energy sources has rapidly been grown to satisfy the increased demand for energy consumption and environmental protection ${ }^{1.2}$ as fossil fuels. which are not renewable or sustainable, are being depleted. Biomasses are very promising in this regard because they could be continuously supplied from plant. Among many ways to utilize them. biofuel cells can be one of the best candidates as a renewable energy source in that various biomasses are directly converted to electricity and highly efficient operation is possible. The main types of biofuel cells are defined by the type of biocatalyst. Enzyme fuel cells use enzyme as catalyst. ${ }^{3}$ whereas microbial fuel cells employ living microorganisms to catalyze organic or inorganic substrates for electricity generation. ${ }^{+6}$

Comparing with other energy generating systems. MFCs offer many advantages: First. operations under mild conditions such as ambient temperature. near neutral $\mathrm{pH}$. and normal pressure are possible. Second. a variety of fuels are available and fuel supply is virtually unlimited. Any biodegradable organic matter can be used in an MFC. Despite extensive research. however. the application of an MFC to the real world has been hindered mainly because of its low power density. This is due to the intrinsic slow kinetics of substrate oxidation. Tens of thousands times or even million times lower power density than that of inorganic fuel cells has been taken into granted until recently. Many measures. therefore. have been taken to improve the performance of an $\mathrm{MFC}$. Reducing the electrode spacing ${ }^{7}$ increasing solution conductivity by varying the solution ionic strength. ${ }^{8}$ and using new cathodic electron acceptors such as permanganate are among those efforts. At the same time. many researchers have paid attention to improving electrode materials. Many new cathodic materials based on non-noble metals have been developed for the oxygen reduction. Increasing efforts have also been made for anodes. For example. binding the mediator. neutral red to the anode increased current by 10 fold using Shev'anella purefaciens. ${ }^{10}$ Output power was boosted by $48 \%$ with ammonia treated carbon cloth anodes. ${ }^{11}$ Use of composite graphite/PTFE anodes improved performance of an $E$. coli-catalyzed MFC. ${ }^{\text {12 }}$

In the meantime, conductive polymers. since they were first electrochemically synthesized more than two decades ago. ${ }^{13}$ have attracted great interest due to their potential applications in preparing actuators. (bio)chemical sensors. electrodes. and electronic devices. ${ }^{1+-18}$ possessing many interesting properties such as environmental stability. ease of synthesis. and high conductivity at room temperature. ${ }^{19}$ They are also widely used as electrode materials in fuel cells. Schröder and Scholz reported that (fluorinated) polyaniline-modified platinum anode gave one order of magnitude increase in current outputs. ${ }^{2.21}$ Furukawa also used modified polyaniline to enhance the performance of MFC. ${ }^{19}$ Modified polyaniline functioned as a mediator to directly shuttle electrons between microorganism and electrode instead of using an exogenous mediator such as methỵlene blue. However. the relatively lower conductivity and poor electron transfer properties of polymers limit further performance improvement of MFCs.

Here we present polypyrrole/carbon black (Ppy/CB) composite as a new anode material for the higher energy output. The result showed that a composite-modified carbon paper anode gave a better performance than when individual components were used. This type of conductive polymer/ carbon black composite may be the promising anodic material for MFC due to its conmercial availability. low cost. and good electronic properties.

\section{Experimental}

Chemicals and materials. Pyrrole (98\%) and polypyrrole (doped. conductivity $30 \mathrm{~S} \mathrm{~cm}^{-1}$ ) composite with carbon black were purchased from Sigma-Aldrich. Polypyrrole content in 
Ppy $/ \mathrm{CB}$ was $20 \mathrm{wt} \%$. Carbon paper was purchased from ETEK. Vulcan XC72 (Carbot Corp.) was used as high area carbon to modify carbon paper. All other chenicals were of analytical grade and used as received unless otherwise stated. Deionized water (resistivity over $18 \mathrm{M} \Omega \mathrm{cm}$ ) from an aquaMAX ${ }^{\mathrm{IM}}$-Ultra (Younglin, Korea) water purification systent was used in all experiments.

Preparation of microorganism. Protets nilgaris (ATCC 6059) was obtained from KCTC (Korean Collection for Type Cultures) and maintained on a nutrient agar plate at 4 ${ }^{\circ} \mathrm{C}$. The experimental culture was aerobically grown in a nutrient badge containing $3 \mathrm{~g} \mathrm{~L}^{-1}$ of yeast extract and $5 \mathrm{~g} \mathrm{~L}^{-1}$ tryptone at $37^{\circ} \mathrm{C}$. The cells were harvested by centrifuging at $8000 \mathrm{~g}$ for $10 \mathrm{~min}$ and washed with $0.1 \mathrm{M}$ phosphate buffer solution $(\mathrm{pH} \mathrm{7.0)}$. The washed microorganisms were resuspended in the same phosphate buffer solution for the experiments. Glucose was used as a fuel.

Anode preparation. A carbon paper sheet $(18 \mathrm{~mm} \times 18$ $\mathrm{mm}$ ) was thoroughly washed by ethanol and distilled water consecutively before coating a composite film. $0.0 \mathrm{lng}$ of polypyrrole/carbon composite was dispersed into $2 \mathrm{~mL}$ ethanol under ultrasonication for $2 \mathrm{~min}$. The carbon paper sheet was then sunk in mixed solution for $3 \mathrm{~min}$. After drying at room temperature to remove ethanol. the electrode was used as an anode for MFC experiments. Polypyrrole film was also formed electrochemically for the comparison purpose. Electrodeposition of Ppy was done on a piece of carbon paper by applying $+0.9 \mathrm{~V}$ for $10 \mathrm{~min}$ using a potentiostat (PGSTAT 3.0. Autolab, The Netherlands). After washing it with deionized water, Ppy-coated carbon paper was dried at $70^{\circ} \mathrm{C}$ in an oven before use.

Impedance measurements. Inipedance spectroscopy was used to analyze internal resistance of an MFC over a frequency range of $\mathrm{I} \times 10^{*}$ to $0.005 \mathrm{~Hz}$ between the anode and cathode (two electrode mode). Impedance measurements were conducted at open-circuit potential with a sinusoidal perturbation of $5 \mathrm{mV}$ amplitude. The cell was discharged with a $1000 \Omega$ extemal load for more than $l \mathrm{hr}$ and then polarized at $0.3 \mathrm{~V}$ for at least $15 \mathrm{~min}$ before the measurements. The internal resistance was obtained by plotting a Nyquist plot $\left(Z_{\text {in }}\right.$ \&s $Z_{\text {re }}$ as a function of $\left.\omega\right)$. The senti-circle part was taken to obtain ohmic resistance of the electrolyte $\left(R_{\delta 2}\right)$ and charge transfer resistance $\left(R_{\mathrm{tt}}\right)$. Intercepts of the fitted curve with $Z_{\text {re }}$ axid at higher and lower frequencies are $R_{Q 2}$ and $R_{\Omega 2}+R_{\mathrm{ct}}$. respectively. The sum. $R_{\Omega 2}+R_{\mathrm{ct}}$ is considered as the total internal resistance. ${ }^{32,23}$

Fuel cell assembly. A fuel cell used in our experiments was composed of anodic and cathodic compartments (internal dimension: $20 \mathrm{~mm} \times 20 \mathrm{~mm} \times 1 \mathrm{~mm}$ ) separated by the cation exchange membrane (Nafion 117. Aldrich). The Anode and cathode were Ppy/CB composite coated carbon paper and carbon paper. respectively. Carbon paper was washed with $75 \%$ alcohol and deionized water. dried at 70 ${ }^{\circ} \mathrm{C}$ in an oven. and then placed in a phosphate buffer solution $(100 \mathrm{mM})$ before use. In these experiments. we employed a mediator-type MFC where thionin was used as a mediator. Ferricyanide $(0.1 \mathrm{M})$ was used as an electron acceptor in the cathodic compartment. Both anode and cathode compartments contained $0.1 \mathrm{M}$ phosphate buffer $(\mathrm{pH} 7.0)$ as electrolyte. The Nafion membrane was pretreated by successively boiling in $3 \%$ hydrogen peroxide for $1 \mathrm{~h}$, in $1 \mathrm{M}$ sulfuric acid for another $\mathrm{l} h$, in boiling deionized water for $\mathrm{l} h$, and then stored in deionized water prior to use

Extennal loads of various resistance values were inserted between the anode and the cathode to construct polarization curves. The cell potential was measured using an automatic battery cycler (WBCS 3000 , WonAtech, Korea) as a function of time. We expressed our results in power density per unit surface area.

\section{Results and Discussion}

Performance test of MFCs with different anodes. Figure I shows SEM images of carbon paper before (a) and after (b) Ppy/CB coating. Carbon paper has a three-dimensional structure composed of intertwined carbon fibers and sheet. through which bacteria can freely go in and out. Ppy/ $\mathrm{CB}$ coating makes most free space filled with carbon paste so that it offers an ideal environment for bacteria to reside inside.

Figure 2 shows cell voltage and power density plots ws current for different anodic materials. When a carbon paper was used without any modification (panel A), the maximum power density was only $151 \mathrm{~mW} \mathrm{~m}^{-2}$. Upon carbon black coating on the carbon paper surface (panel B), however, much increase in output power to $250 \mathrm{~mW} \mathrm{~m} \mathrm{~m}^{-3}$ was observed. It is due to the effect of the increased surface area, making a large number of mediator molecules as well as bacteria have easy access to the anode for the rapid electron transfer. Further increase was observed when $\mathrm{Ppy} / \mathrm{CB}$ composite powder was used to modify the anode (panel $\mathrm{C}$ ). About $350 \mathrm{~mW} \mathrm{~m}^{-2}$ power density was achieved with a loading of $0.75 \mathrm{mg}$ per unit area (in $\mathrm{cm}^{3}$ ). The possible reasons for the improvement are as follows: First. positively charged Ppy increases adhesion of negatively charged bacteria to the surface through electrostatic interaction. thus making facile electron transfer to the anode. Cell voltages monotonically decreased with current in all three cases.
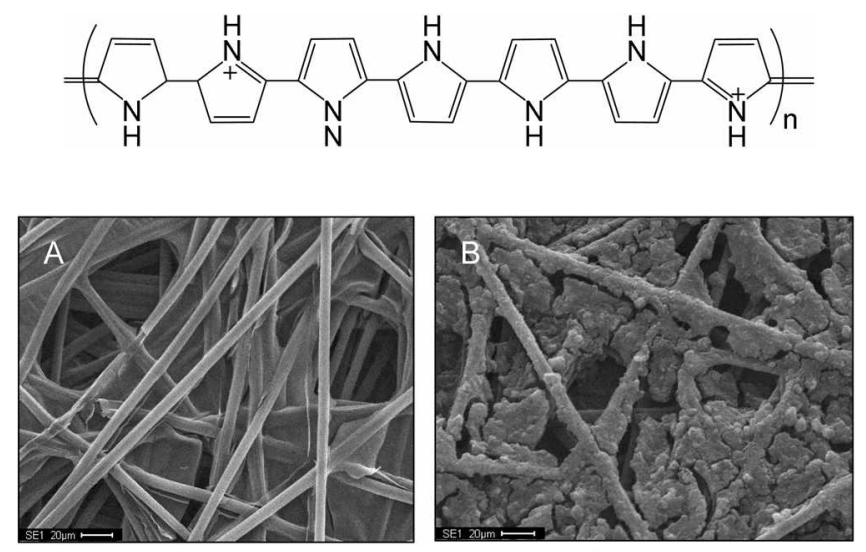

Figure 1. SEM images of carbon paper before (A) and after (B) $\mathrm{Ppy} / \mathrm{C} \mathrm{C}$ coating. 

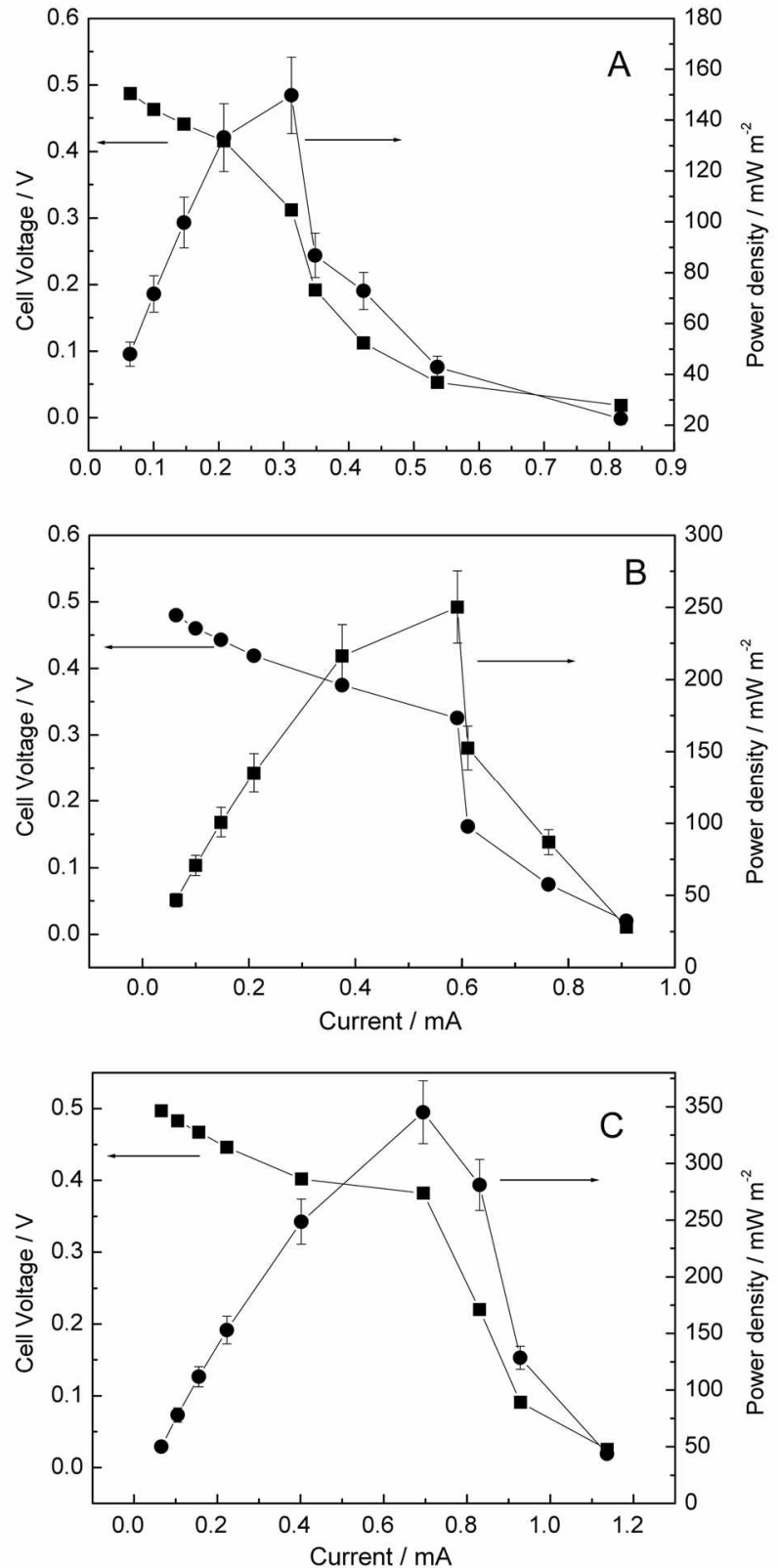

Figure 2. Plots of cell voltage ( $\mathbf{n}$ ) and power density (u) vs current for no modified (panel A), CB-coated (panel B), and Ppy

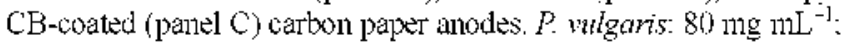
Thionine: $0.5 \mathrm{mM}$; Glucose: $0.01 \mathrm{M}$; Ferricyanide: $0.1 \mathrm{M} .0 .1 \mathrm{M}$ phosphate buffer solution was used as electrolyte.

The similar strategy has been adapted by $\operatorname{Logan}^{2-4}$ when he treated carbon cloth anode with ammonia to impart positive charge on the surface. They observed enhanced power generation. Second. Ppy could act as a mediator itself. The long Ppy chain can penetrate the bacterial cell membrane to take electrons from the metabolic pathway to the anode. Similar results were reported by Funukawa et al ${ }^{13}$ who used polyaniline-coated carbon fiber in direct photosynthetic/metabolic biofuel cell for the enhanced performance. Usefulness of carbon black was demonstrated by comparing power density plots from Ppy/CB-coated anode and from only Ppycoated anode (data not shown). Lower power density was

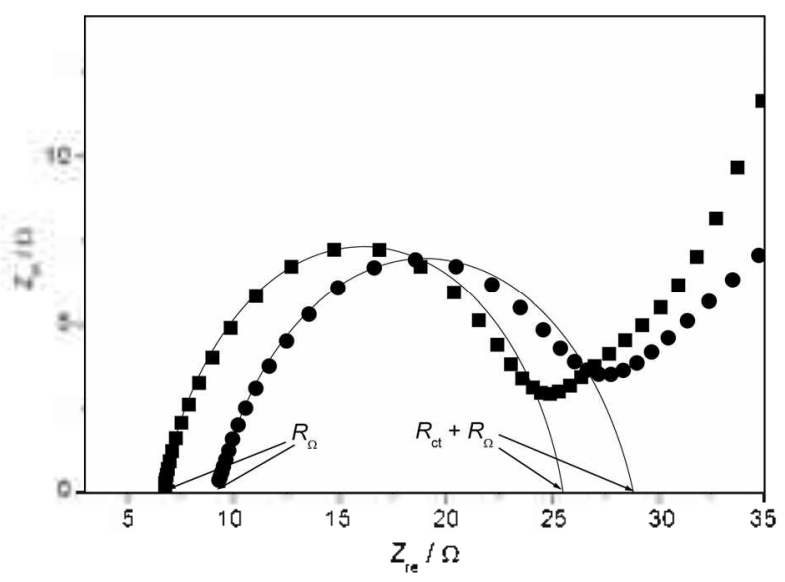

Figure 3. Nyquist plot for the plain carbon paper and Ppy/CBcoated carbon paper. Semi-circle parts were fitted to obtain $R_{\Omega}$ and $R_{\text {ct. }}$

resulted for the latter case.

More insight could be obtained by analyzing impedance spectroscopy. Nyquist plots (Fig. 3) were made on the plain carbon paper and Ppy/CB-coated carbon paper electrodes under the same experimental conditions. Curve fitting of the semi-circle parts gave the solution resistances $\left(R_{52}\right)$ of 9.2 and $6.7 \Omega$, and charge transfer resistances $\left(R_{\mathrm{ct}}\right)$ of 19.6 and $18.8 \Omega$ for the plain carbon paper and Ppy/CB-coated electrodes, respectively. making the total intemal resistance $\left(R_{\Omega !}+R_{\mathrm{ct}}\right)$ reduced from 28.8 to $25.5 \Omega$. This result clearly indicates that Ppy/CB provides beneficial effects on the fuel cell operation.

To examine the function of polypyrrole. polypyrrole was electrodeposited onto the carbon paper and cell performance was test (Fig. 4). Although the obtained maximum power density ( $303 \mathrm{~mW} \mathrm{~m}^{-3}$ ) is certainly larger than that of carbon paper $\left(151 \mathrm{~mW} \mathrm{~m}^{-\hat{2}}\right)$. it is smaller than that of Ppy/CB (452 $\mathrm{mW} \mathrm{m}^{-2}$ ). The same effect was observed in an experiment using a reticulated vitreous carbon anode. ${ }^{2}$ This result shows that synergistic effect works when both carbon black and polypyrrole are present in anode.

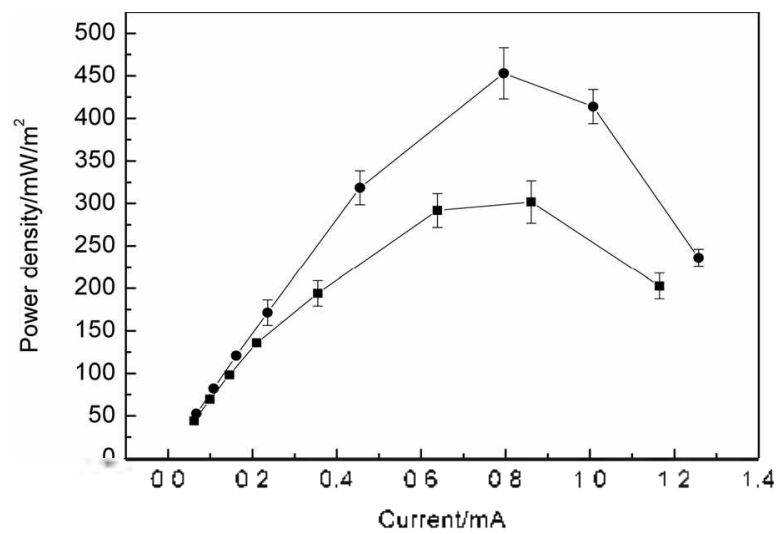

Figure 4. Power density plot of an MFC with different anodes, Ppy/CB ( $)$ and electrodeposited Ppy anode ( $\bullet$. Electrodeposition of $\mathrm{Ppy}$ on the carbon paper was done by applying $+0.9 \mathrm{~V}$ for 10 $\min$ 

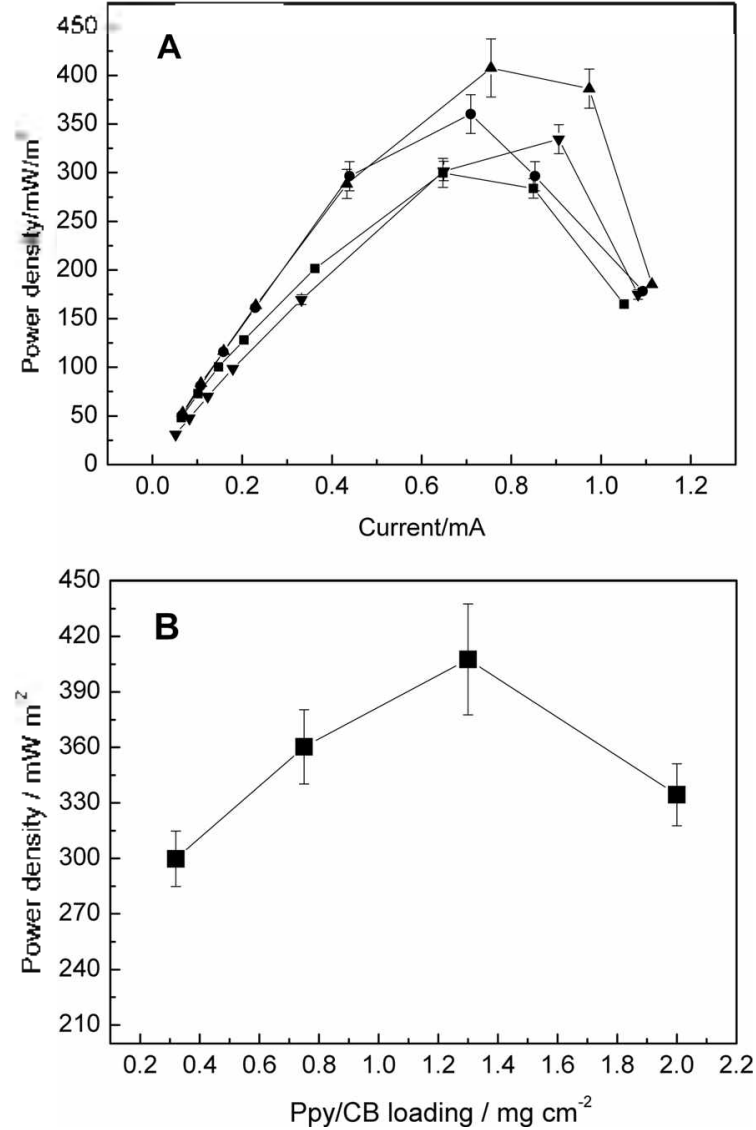

Figure 5. (Panel A) Power density plot vs cument for the different loaded amount of Ppy/CB: 0.32 ( $), 0.75,1.3$ (A) and $2.0 \mathrm{mg} \mathrm{cm}-1$ ( $\mathbf{\nabla}$ ). (Panel B) Plot of power density vs loaded amount.

Power density is not always proportional to the amount of Ppy/CB (Fig. 5). The highest power output was obtained with $1.3 \mathrm{mg} \mathrm{cm}{ }^{-3} \mathrm{Ppy} / \mathrm{CB}$. A higher loading rather led to the perfomance decrease. This could be ascribed to the hindered mass transport to the electrode because of reduced pore size.

Effect of mediators. It has been pointed out that fuel cells composed of non-exoelectrogens. exogenous mediators are required to enhance fuel cell performance. whereas exoelectrogens such as Shew:anella and Geobacters where cytochromes are localized to the outer membrane do not need mediators. Since $P$. vilgaris is not an exoelectrogen. we employ'ed several types of mediators. Mediators are interacting with the metabolic pathway of the microorganisms to shuttle the electrons from intracellular space to extracellular environment. the anode. We chose thionin and methylene blue (MB) as phenothiazine derivatives. and neutral red $(\mathrm{NR})$ as a phenazine molecule. These molecules have been known functioning as good mediators. Figure $6 \mathrm{~A}$ shows that the phenothiazine-ty'pe mediators are better than phenazinetype mediators as also reported by Ieropoulos et $a$. who tested different types of mediators for a prototype MFC using $E$. coli ${ }^{25}$ It may be due to the fact that different types of mediators act to the different parts of a metabolic pathway $:{ }^{\circ}$ According to Wilkinson. NR most likely interacts
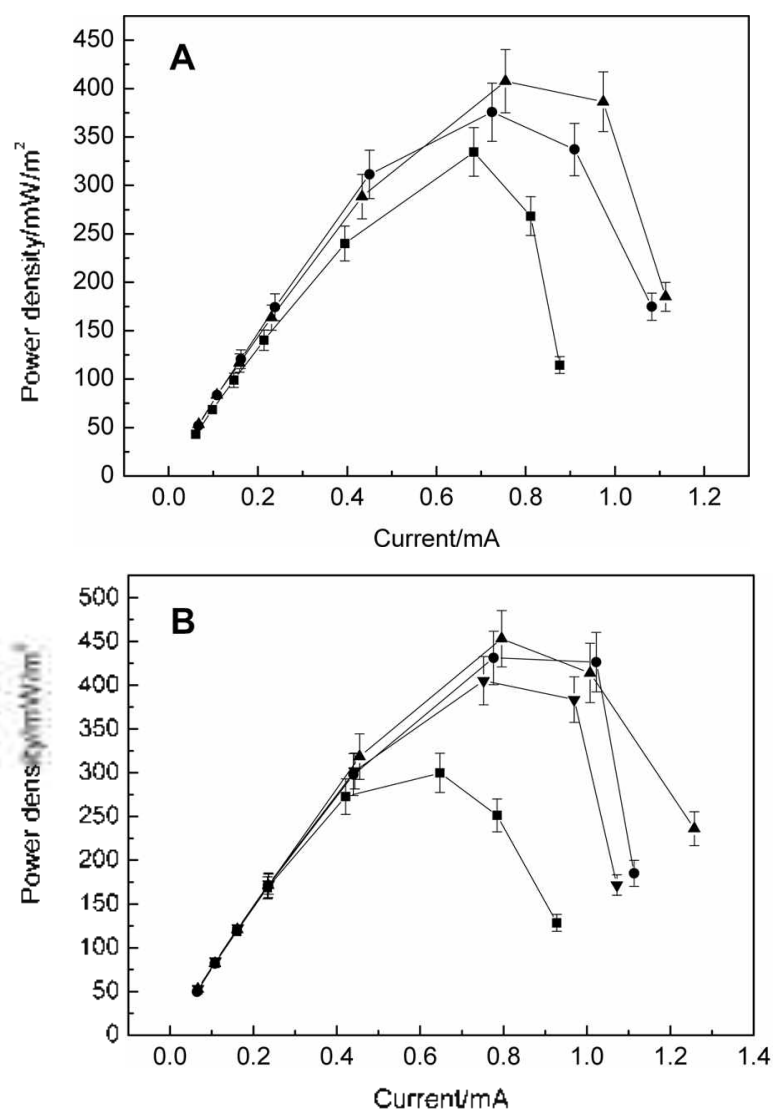

Figure 6. (Panel A) Effect of types of a mediator on the power density: Neutral red $(\boldsymbol{\square})$ : methylene blue $(\bullet)$ ) thionin $(\boldsymbol{\Delta})$ ). (Panel B) Power density plot vs current for the different concentrations of thionin: $0.125(\boldsymbol{\square}) 0.25(\bullet) ; 0.40(\bullet), 1.0 \mathrm{mM}(\boldsymbol{\nabla})$.

with fermentation pathway. not with respiration pathway. which leads to less production of electrons.

The optimum mediator (thionin) concentration was also investigated with all other conditions fixed (Fig. 6B). Up to $0.4 \mathrm{mM}$. the power density increased with the concentration. reaching the maximum at $0.4 \mathrm{mM}$. This is because the electron transfer rate is proportional to the number of mediators.

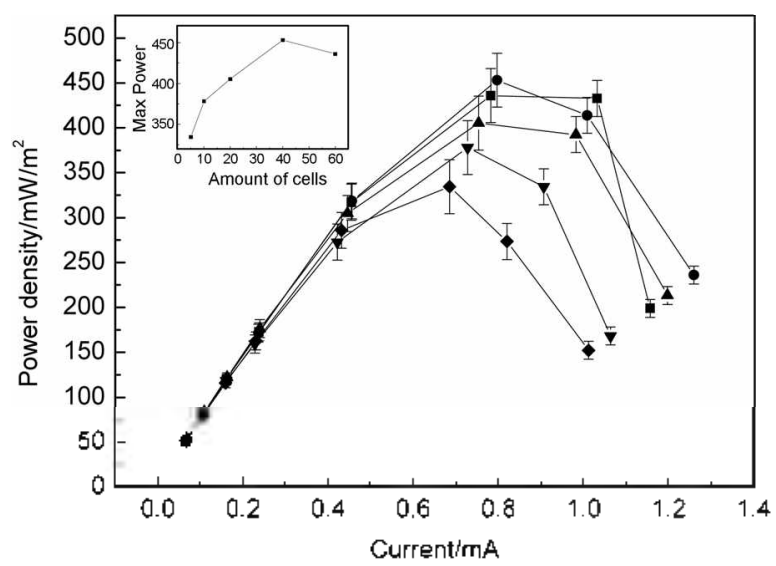

Figure 7. Power density plot vs current for the different amount of P. vilgais: $5(\diamond), 10(\nabla), 20(\Delta), 40(\bullet)$, and $60(\square) \mathrm{mg} \mathrm{mL}^{-1}$. Inset: Plot of maximum power density ys amount of the cells. 
On the contrary to our expectation, however, at the higher concentrations than $0.4 \mathrm{mM}$, the power density decreased with the increase in concentration. indicating there is optinum mediator concentration. Too high concentration may have toxicity to the bacteria or the uureduced thionin hinders the electron transfer by being adsorbed on the bacterial cell memibrane.

Effect of the amount of bacteria on the power output. The number of bacteria was also shown to affect the power output when other conditions were fixed (Fig. 7). The power density increased rapidly with the increasing number of bacterial cells and then decreased. In our present conditions. $60 \mathrm{mg} \mathrm{mL} \mathrm{mL}^{-1}$ was the optimum anount of $P$. whlgaris for the maxinum power. $10 \mathrm{ntg}$ (dry weight) $\mathrm{mL}^{-1}$ solution contains ca. $2 \times 10^{8}$ cells. The fact of no further increase with the larger number of cells indicates that there is optimal effective number of bacterial cells for a given electrode geometry and fuel cell configuration.

\section{Conclusions}

This study has shown that a polypyrrole/carbon black composite is very effective naterial for the MFC operation in high power density. It was found that both polypyrole and carbon black should be present on the anode to have synergistic effect. Otherwise not nuch increase in power density was observed with single components. Our obtained value of $452 \mathrm{~mW} \mathrm{~m}^{-2}$ is the highest anong the MFC systems using $P$. vilgaris. The effects of anount of $\mathrm{Ppy} / \mathrm{CB}$, mediator concentration, and amount of $P$. vulgaris have also been examined

Acknowledgments. This work was supported by Korea Research Foundation (KRF 2005-070-C00084).

\section{References}

1. Boudghene Stambouli. A.: Traversa. E. Renew: Sistain Energy Rev 2002. 6, 295.
2. Davis. F.: Séamus. P.: Higsont. J. Biosens. Bioelectron 2007. 22. 1224.

3. Minteer. S. D.: Liaw. B. Y.: Cooney. M. T. Chm: Opinion Biotechnol. 2007. 18,228

4. Rabaey, K.: Verstrate, W. Trends Biotechol. 2005, 23. 291.

5. Choi. Y.: Jung. E.: Park, H, Jung, S.: Kim, S. Bull Koman Chem. Soc. 2007.28 .1591 .

6. Shin. S.-H.: Choi. Y.: Na. S.-H.: Jung. S.: Kim. S. Bull. Korean Chent Soc. 2006. 27. 281 .

7. Cheng. S. A.; Liu. H.; Logan, B. E. Environ. Sci. Technol. 2006 40. 2426 .

8. Liu. H.; Cheng. S. A.; Logan. B. E. Enwiron. Sci. Technol. 2005. 39. 5488

9. You. S. J.: Zhao. Q. L.: Zhang. T. N.: Tiang. T. Q.: Zhao. S. Q. J. Power Sonte 2006. 162. 1409

10. Park. D. H. Zeikus. J. G. Appl Aficrobiol. Biotechol. 2002. 59. 58.

11. Chen. S. A.: Logan. B. E. Electrochem. Commun. 2007.9, 492.

12. Zhang. T.: Zeng. Y. L.: Chen. S. L.: Ai. X. P.: Yang. H. X. Electrochent Conmum. 2006. 8.349.

13. Diaz. A. F.: Kanlazawa. K. K.: Gardini. G. P. J. Chem. Soc. Chent. Commun. 1797, $1+, 635$.

14. Greene. R. L.: Street, G. B. Science 1984, 226.651.

15. Parthasarathy: R. V:; Martin, C. R. Nature 1994, 369, 298

16. Adam. H: Agata. M: Andrzej. L. Talonta 1994. H1. 323.

17. Li. C. M.: Sun1. C. Q.: Song. S.: Choong. V. E.: Maracas. G.: Zhang. X. T. Frontiers Biosci. 2005. 10. 180.

18. Fan. L. Z.: Joachim. M. Electochem. Commm. 2006. 8.937.

19. Schroeder, U.: Niessen. J.: Scholz. F. Angew. Chem. Int. Ed. 2003. 42. 2880.

20. Niessen. I.: Schröder. U.: Rosenbaumn. M.: Scholz. F. Electrochem. Conmum. 2004. 6.571.

21. Furukawa. Y: Moriuchi. T.: Morishima. K. J. Micromech. Aichoeng. $2006,16, \mathrm{~S} 220$.

22. Logan, B. E.: Cheng, S:; Watson, V; Estadt, G. Ewiron. Sci Techol. 2007. 41,3341 .

23. He. Z.: Wagner. N.: Mitteer. S. D.: Angenent. L. T. Emiront Sci Technol. 2006. 40.5212 .

24. Yuan. Y.: Kim. S. Bull. Korean Chem. Soc. 2008. 29. 168.

25. Wilkinson. S.: Klar, J:- Applegarth, E. S. Electroonal. 2006, 18. 2001.

26. Cheng. S.: Logan. B. E. Electrochem. Commum. 2007.9. 492.

27. Ieropoulos. I. A.: Greenman. J.: Melhuish. C.: Hart. T. Enz. Microbial Technol 2005, 37. 238.

28. Wilkinson. S.: Klar. J.: Applegarth. E. S. Electromal. 2006. 18. 2001 . 